\title{
Full-scale biodrying process of municipal solid waste
}

\author{
Marlena Dębicka ${ }^{1 *}$, and Maria Żygadło ${ }^{1}$ \\ ${ }^{1}$ Kielce University of Technology, Faculty of Environmental, Geomatic and Energy Engineering, \\ Division of Waste Management, 25-314 Kielce, al. Tysiąclecia PP 7, Poland
}

\begin{abstract}
The paper presents the results obtained in the full-scale waste biodrying reactor. The studied facility includes in the biological stage a rectangular-shaped, galvanized steel reactor equipped with a module for active aeration connected with a stove and a bio-filter for removing odours. The undersize fraction $(\varnothing<80 \mathrm{~mm})$ of the municipal solid waste (MSW) that undergoes mechanical pretreatment is treated by $14^{\text {th }}$ days in the $150 \mathrm{~m}^{3}$ capasity reactor. Initial moisture content of the untreated waste was $54.65 \%$. Moisture content was declined gradually during biodrying process. Temperature changes during 14 th days of biodrying process were monitored with the maximum temperature $70^{\circ} \mathrm{C}$. To assess the degree of stabilization of the biodried waste, the determination of the $\mathrm{O}_{2}$ uptake was measured. The oxygen demand of untreated waste was $53.16 \mathrm{mg} \mathrm{O}_{2} / \mathrm{g} \mathrm{d}$.m. and after $14^{\text {th }}$ days for biodried waste oxygen consumption was $19.78 \mathrm{mg}$ $\mathrm{O}_{2} / \mathrm{g}$ d.m. The results obtained in studies by respirometric dynamic method of oxygen uptake (expressed as $\mathrm{O}_{2} / 96 \mathrm{~h}$ parameter) had been compared to the results performed using the static method, where $\mathrm{AT}_{4}$ is the applied indicator.
\end{abstract}

\section{Introduction}

Common and widely studied mechanical-biological treatment (MBT) of aerobic waste systems are composting and stabilization [1]. Biodrying is a new variation of MBT processes that removes convective moisture allowing to produce highly calorific output $[2,3]$. Wastes after biodrying process with low moisture content and enhanced calorific value, are not completely biologically stable, but can be used as a source of refuse derived fuel (RDF). These RDFs should be used immediately, without storage [4-7].

Drying technology has been developed within the scope of food, agricultural, pharmaceutical, paper and other industries [8]. The basic parameters that affect municipal solid waste (MSW) biodrying are process temperature, moisture content, aeration efficiency and reactor design. So far biodrying research in laboratory- and full- scale are limited. Investigations on $480 \mathrm{dm}^{3}$ lab-scale reactor resulted in increasing the sorting efficiency of post product by $\sim 40 \%$, higher heavy metals concentration in dry mass by $60 \%$ and lower heating value by $\sim 160 \%[9,10]$. Experience of a $240 \mathrm{dm}^{3}$ lab-scale reactor included

* Corresponding author: mdebicka@tu.kielce.pl 
searching for design of a drying tunnel allowed to produce high calorific biofuel [11]. In the literature it has been reported studies on the influence of temperature and air-flow rate on the biostabilization-biodrying of municipal solid waste in the $148 \mathrm{dm}^{3}$ lab-scale reactor $[12,13]$. It was estimated, that temperature optimal for biodrying process is $45^{\circ} \mathrm{C}$, while in the composting and the stabilization the temperature can rise up to $70^{\circ} \mathrm{C}$.

In order to understand the science and engineering of biodrying processes adequately, it is necessary to make investigations in full-scale facilities. The article presents the results of temperature changes, microbial activity and moisture content variation observed in fullscale biodrying facility. Results obtained in our study have been compared to results reported for other full-scale MSW biodrying experiments.

\section{Materials and methods}

The layout of the technology is schematically presented in Figure 1. The biodrying stage has the following specifications:

- feedstock characteristics: $0-80 \mathrm{~mm}$ fraction of municipal solid waste, containing $\sim 40 \%$ of biodegradable waste, $\sim 40 \%$ of mineral contaminates (glass, ceramic, metals, other minerals), $\sim 12 \%$ of plastic, foil, textiles and $\sim 8 \%$ of fraction $<10 \mathrm{~mm}$.

- reactor capacity and retention time: $50-60 \mathrm{Mg}$ treated by $14^{\text {th }}$ days,

- major equipment: the rectangular-shaped reactor made from galvanized steel,

- remaining equipment: the bio-filter that removes odours, the stove used optionally in specific winter conditions, rotating drum,

- aeration system: the supply ventilator (air flow $4500 \mathrm{~m}^{3} \mathrm{~h}^{-1}$ using $7.5 \mathrm{~kW}$ power) and the exhaust ventilator (air flow $3000 \mathrm{~m}^{3} \mathrm{~h}^{-1}$ using $4 \mathrm{~kW}$ power),

- final products: $20-80 \mathrm{~mm}$ fraction biodried waste can be used as a refuse derived fuel RDF and finally combusted, $0-20 \mathrm{~mm}$ fraction directed to stabilization process and would be finally landfilled.

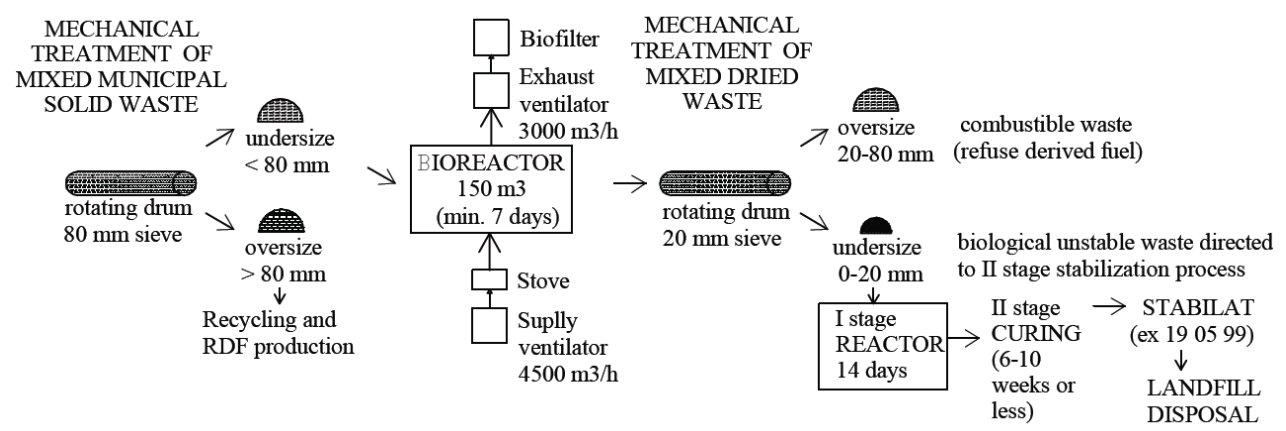

Fig.1. Technology concept in the studied MBT plant.

Samples were taken according to regulatory requirements [14]. The water content was calculated based on the weight loss in the $1000 \mathrm{~g}$ sample at $105^{\circ} \mathrm{C}$ [15]. The measurement of the loss on ignition (LOI) was determined in a muffle furnace at $550^{\circ} \mathrm{C}$ by 6 hours using $5 \mathrm{~g}$ samples according to the Polish Standard [16]. The temperature inside the biomass was measured 5 times per day in the different reactor parts using 2-metre lance. The biological stability was determined by dynamic aerobic test using a respirometer Oxymax ER-10, which allows to measure the $\mathrm{CO}_{2}$ production and the $\mathrm{O}_{2}$ uptake during the time. The respiration activity should be measured in an oxidic atmosphere, for the $30 \mathrm{~g}$ minimum mass sample with a humidity of $40-50 \%$ [17]. By means of a respirometer, a number of 
measurements were taken in time intervals every 5 minutes, recording the net increase or decrease in the concentration of the monitored gases. The microbial activity $\mathrm{AT}_{4}$ was investigated in accredited laboratory in Pszczyna according to internal procedure.

\section{Results and discussion}

\subsection{Temperature and moisture variation}

Initial moisture content of the untreated waste was 54.65\%. Moisture content (MC) were declined gradually during biodrying process. The main mechanism of water removal was the evaporation of water as a consequence of microbial heat generation. In our study the biodrying processes were completed with $35.04 \%$ of moisture content. Thus the drop of moisture at $20 \%$ content was obtained during studied biodrying process. Similar results had been reported by Zawadzka et al. and Hurka \& Malinowski [11, 18]. According to [19] the continuous decrease in the feedstock humidity could be additional indicator of the organic matter decomposition, because in result of biodrying process about $28 \%$ of initial waste mass was evaporated as a $\mathrm{CO}_{2}$ and $\mathrm{H}_{2} \mathrm{O}$. Similar results had been reported in publications $[20,21]$.

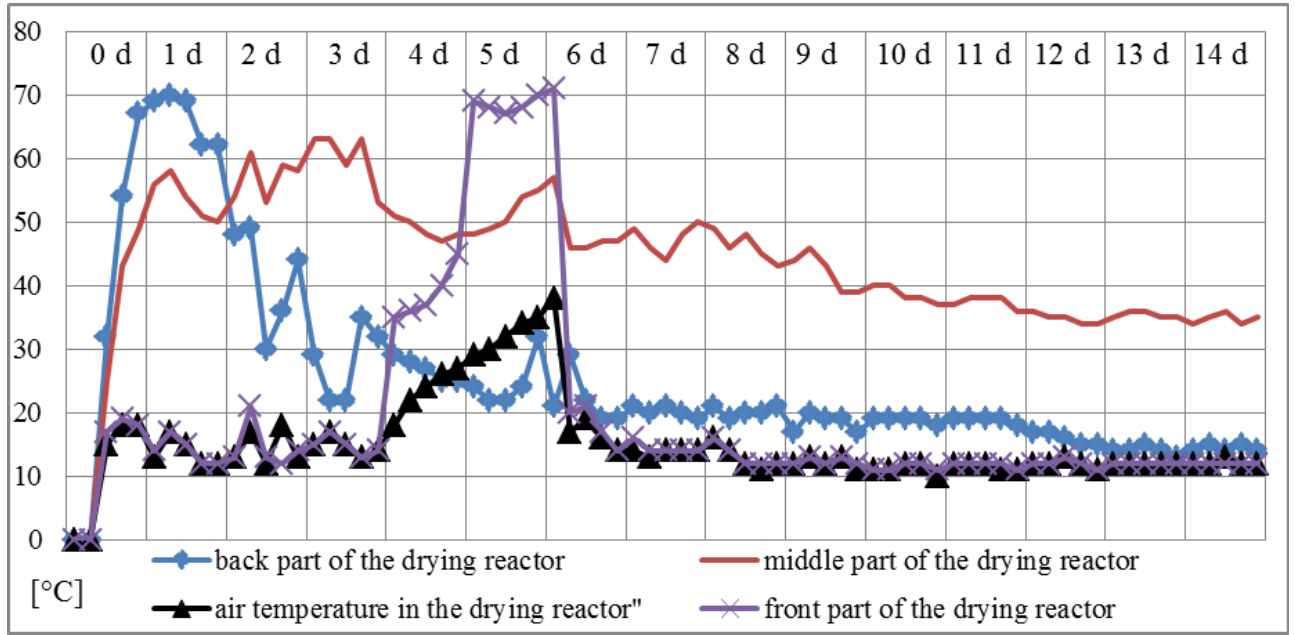

Fig. 2. Temperature changes during 14th days biodrying process registered in different reactor areas.

Temperature changes registered in the different reactor parts are presented in Fig. 2. The feedstock temperature was monitored 5 times per day in the front, middle and back part of the drying reactor. Temperature is also the factor that allows to assess the microbial activity. The highest temperature about $70^{\circ} \mathrm{C}$ was recorded in the middle part of the reactor while the average level was $43.45^{\circ} \mathrm{C}$, similar to Dziedzic et al. [22]. The lowest temperatures were registered in the front part of the reactor. Temperatures in the middle part in the reactor was optimal for the biodrying process as was estimated by Tambone et al. [23] (about $45^{\circ} \mathrm{C}$ ). Rapid increase in the temperature values was recorded during 5th day, what needed to switch off the aeration system. After 6th day temperature was contentiously decreased and the aeration system was switched on again. 


\subsection{Organic matter degradation}

The reactivity/stability of the MBT products can be determined by aerobic and anaerobic methods. Respiration techniques based on the measurement of the loss of $\mathrm{O}_{2}$ are the most accepted because of the precise information about the real biological activity of the samples [24]. The parameter $\mathrm{O}_{2} / 96 \mathrm{~h}$ obtained during respiration technics presents the microbiological oxygen consumption over 4 days and determines the ability of the waste for further biological decomposition. Table 1 summarizes the data respiration activity of the raw (untreated MSW) 0-80 mm fraction and the dried 0-80 mm fraction. In Poland (till 2016) waste after MBT process should fulfill the requirement of respiration activity level $\mathrm{AT}_{4}<10 \mathrm{mg} \mathrm{O} / \mathrm{g}$ d.m. to be called "stabilat" and than it is allowed to be landfilled [25].

Table 1. The microbial activity measured as changes examined for $0-80 \mathrm{~mm}$ MSW fraction before and after biodrying process in industrial reactor.

\begin{tabular}{|c|c|c|c|c|}
\hline Fraction & $\begin{array}{c}\text { Accumulative } \\
\text { consumption } \\
\mathrm{O}_{2} \\
\end{array}$ & $\begin{array}{c}\text { Accumulative } \\
\text { production } \\
\mathrm{CO}_{2} \\
\end{array}$ & $\begin{array}{c}\text { Consumption } \\
\mathrm{O}_{2} / 96 \mathrm{~h}\end{array}$ & $\overline{\mathbf{A T}_{4}}$ \\
\hline Unit & {$\left[\mathrm{mg} 96 \mathrm{~h}^{-1}\right]$} & {$\left[\mathrm{mg} \mathrm{96} \mathrm{h} \mathrm{h}^{-1}\right]$} & $\begin{array}{c}{\left[\mathrm{mg} \mathrm{O}_{2} \mathrm{~g}\right.} \\
\left.\text { d.m. }{ }^{-1}\right]\end{array}$ & $\begin{array}{c}{\left[\mathrm{mg} \mathrm{O}_{2} \mathrm{~g}\right.} \\
\left.\text { d.m. }{ }^{-1}\right]\end{array}$ \\
\hline $\begin{array}{l}\text { Untreated } \\
\text { waste }\end{array}$ & 3117.47 & 3578.19 & 53.16 & not measured \\
\hline $\begin{array}{l}\text { Biodried } \\
\text { waste }\end{array}$ & 1782.15 & 1939.48 & 19.78 & 14.30 \\
\hline
\end{tabular}

The results obtained in the studies by respirometric dynamic method of oxygen uptake (expressed as $\mathrm{O}_{2} / 96 \mathrm{~h}$ parameter) had been compared to the results performed using the static method, where $\mathrm{AT}_{4}$ is the applied indicator. Indicator $\mathrm{AT}_{4}$ is not satisfied, because its value exceeds $10 \mathrm{mg} \mathrm{O} / \mathrm{g}$ d.m.

According to the data presented in Table 1 the starting microbial activity measured as oxygen demand for untreated waste, expressed as $\mathrm{O}_{2} / 96 \mathrm{~h}$ parameter, was $53.16 \mathrm{mg} \mathrm{O} / \mathrm{g}$ d.m. That suggests high degree of microbial activity and capability to biodegradation of organic matter. Biodried waste was characterized by lower oxygen consumption and expressed as $\mathrm{O}_{2} / 96 \mathrm{~h}$ parameter, was $19.78 \mathrm{mg} \mathrm{O} / \mathrm{g}$ d.m. Decreasing of oxygen demand parameter allows to make the conclusion that the biodried waste undergone stabilization. It was accomplished in 14 days at a certain level. It is called "drying effect" that occurs when the amount of readily biodegradable matter is completed or when low moisture conditions inhibit microbial activity [26].

Our results had been compared to reports regarding the microbial activity of biodrying waste in the $240 \mathrm{dm}^{3}$ lab-scale reactor, where $\mathrm{O}_{2} / 96 \mathrm{~h}$ parameter was decreased from 8.01 to $0.31 \mathrm{mg} \mathrm{O} / \mathrm{g}$ d.m.. The difference in our and that study can be explained by reactor design and intensity of aeration [27]. Results from 19 full-scale MBT plants (2 with biodrying reactors) showed even average $90 \%$ decrease in the respiration activity index [28].

The results obtained in our studies by respirometric dynamic method of oxygen uptake (expressed as $\mathrm{O}_{2} / 96 \mathrm{~h}$ parameter) had been compared to the results performed using the static method, where $\mathrm{AT}_{4}$ is the applied indicator. Indicator $\mathrm{AT}_{4}$ is not satisfied, because its value exceeds $10 \mathrm{mg} \mathrm{O}_{2} / \mathrm{g}$ d.m.

According to Figure 3 the amount of organic matter (measured as LOI) was decreased during biodrying process. Every point in Fig. 3 is the average of three repetitions. Higher organic matter losses were observed in the middle part of the reactor. The biodegradation in the middle reactor area was faster than in other areas. It is connected with the highest temperature profile and intensified microbial activity. The degradation process slows down due to decreasing microbial activity, that is caused by the lowering water content [22]. 
LOI results from our study were compared with results obtained in a two-stage MBT process in the full-scale $36 \mathrm{~m}^{3}$ reactor using $4500 \mathrm{~m}^{3} / \mathrm{h}$ aeration [22]. In the first stage waste was stabilized for $14^{\text {th }}$ days, than in the second stage 7 -days biodrying was applied. Starting LOI value was $77.1 \%$ d.m., while after stabilization and biodrying amounted to $51.2 \%$ d.m., $48.3 \%$ d.m. respectively. LOI was reduced by $30 \%$, similar to our study but it was still above the value limited by law requirements where LOI should be lower than $35 \%$ d.m. [25].

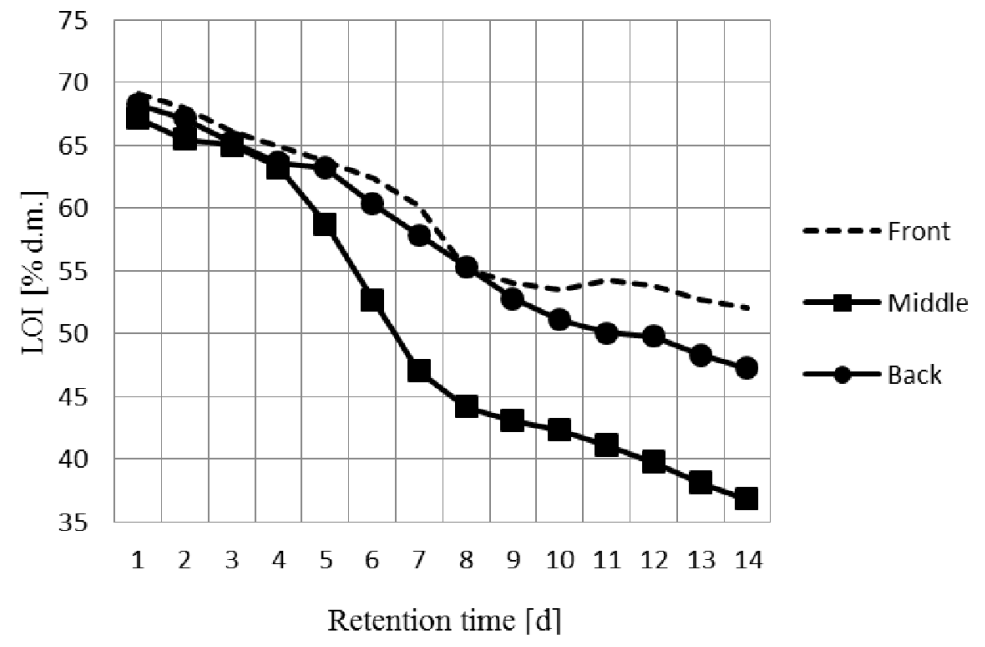

Fig. 3. The loss of ignition measured in the front, middle and back parts of the biodrying reactor during $14^{\text {th }}$ days retention time.

\section{Conclusion}

The MSW undergone the drying process for $14^{\text {th }}$ days in the full-scale reactor. Moisture content was reduced by $20 \%$, while organic matter determined as loss of ignition was reduced by $35 \%$. The highest difference between starting and final values of LOI was observed in the middle part of the reactor where temperatures were about $70^{\circ} \mathrm{C}$.

The respiration activity after biodrying was higher than the limited level of $10 \mathrm{mg} \mathrm{O}_{2} / \mathrm{g}$ d.m, expressed as $\mathrm{AT}_{4}$. However, the amount of $\mathrm{O}_{2} / 96 \mathrm{~h}$ parameter was decreased by $63 \%$.

Summing up the results we must conclude that it is advisable to extend the biodrying process to get $\mathrm{AT}_{4}$ at the required level. For this purpose, it is reasonable to attempt to intensify the level of aeration of reactor after a period of 7 days.

Investigations were led using: OXYMAX respirometer ER-10 (Columbus Instruments). Equipment was founded by MOLAB Project "'The development of laboratories of public universities in Świętokrzyskie Region'”. Number of Project in Kielce University of Technology: POIG 02.02.00-26023/08-00.

\section{References}

1. B. Bilitewski, Mechanical Treatment: Unit Processes. Solid Waste Technology \& Management, 1 (A. John Wiley and Sons, UK, 2011)

2. M. Żygadło, M. Dębicka, Structure \& Environment, 4, 37-72 (2014)

3. E.C. Rada, M. Ragazzi, A. Badea, U.P.B. Sci. Bull, 74, 209-216 (2012)

4. F. Adani, F. Tambone, A. Gotti, Waste Manage, 24, 775-783 (2004) 
5. R. M. Negoi, M. Regazzi, T. Apostol, E.C. Rada, C. Marculescu, U.P.B. Sci. Bull, 71 , 193-204 (2009)

6. A. Elnaas, A. Belherazem, W. Müller, A. Nassour, M. Nelles, at: http://uest.ntua.gr/tinos2015/proceedings/pdfs/elnaas_et_al.pdf

7. M. Malinowski, J. Sikora, Proceedings Ecopole, 1, 223-230 (2014)

8. C.A. Velis, P.J. Longhurst, G.H. Drew and R. Smith, S.J.T. Pollard, Bioresource Technol, 11, 2747-2761 (2009)

9. D. Zhang, H. Zhang, C. Wu, L. Shao, P. He, Waste Manage, 31, 2816-2823 (2011)

10. L. Shao, Z. Ma, H. Zhang, D. Zhang, P. Ge, Waste Manage, 30, 1165-1170 (2010)

11. A. Zawadzka, L. Krzystek, S. Ledakowicz, Environ Prot Eng, 35, 123-133 (2009)

12. F. Adani, D. Baido, E. Calcaterra, P. Genevini, Bioresource Technol, 83, 173-179 (2002)

13. M. Sugni, Calcaterra E., F. Adani, Bioresource Technol, 26, 1331-1337 (2005)

14. Solid recovered fuels. Methods for sampling. PN-EN 15442:2011

15. Municipal solid waste. Examination of combustible property. Determination of the total moisture. PN - 93/Z15008

16. Characterization of waste - Determination of loss on ignition in waste, sludge and sediments. PN - EN 15169:2007

17. R. Barrena, G. d'Imporzano, S. Pons'a, T. Gea, A. Artola, F. V'azquezc, A. S'ancheza, F. Adani, Hazard Mater, 162, 1065-1072 (2009)

18. M. Hurka, M. Malinowski, Infrastructure And Ecology Of Rural, 4, 1127-1136 (2013)

19. A. Domińczyk, L. Krzystek, S. Ledakowicz, Inz. Ap. Chem, 51, 115-116 (2012)

20. M. Dębicka, M. Żygadło, J. Latosińska, Ecol Chem Eng A, 12, 1461-1470 (2013)

21. A. Tom, A. Haridas, R. Pawels, Procedia Technology, 25, 130-137 (2016)

22. K. Dziedzic, B. Łapczyńska-Kordon, M. Malinowski, M. Niemiec, J. Sikora, Chem Process Eng, 36, 381-384 (2015)

23. F. Tambone, B. Scagalia, S. Scotti, F. Adani, Bioresource Technol, 102, 7443-7450 (2011)

24. R.B. Gomez, F.V. Lima, A.S. Ferrer, Waste Manage Res, 37, 37-47 (2006)

25. The Decree of the Minister of the Environment on the municipal solid waste treatment in mechanical biological plants [Journal of Laws of 2012, No. 0, item 1052]

26. D.M. Griffin, Water and microbial stress. Advances in microbial ecology, (Springer, US, 1981)

27. Ł. Abramczyk, A. Domińczyk, R. Ślęzak, R. A. Cichowicz, Acta Innovations, 13, 5-12 (2014)

28. J. Tinter, E. Smidt, K. Böhm, E. Binner, Waste Manage, 30, 1903-1907 (2010) 